\title{
Short- and long-term effects of an offshore wind farm on three species of sandeel and their sand habitat
}

\author{
M. van Deurs", T. M. Grome, M. Kaspersen, H. Jensen, C. Stenberg, T. K. Sørensen, \\ J. Støttrup, T. Warnar, H. Mosegaard
}

DTU Aqua, National Institute of Aquatic Resources, Technical University of Denmark, Jægersborg Alle 1, Charlottenlund Castle, 2920 Charlottenlund, Denmark

\begin{abstract}
Offshore wind farms (OWFs) are being constructed at a high rate due to a high demand, both economically and politically, for sources of renewable energy. We investigated the short-term and long-term effects of an OWF situated in the North Sea off western Denmark (Horn Rev I; global position: $7.84^{\circ} \mathrm{E}, 55.48^{\circ} \mathrm{N}$ ) on 3 ecologically important species of sandeel. Since sandeels display a distinct preference for sand habitats with a weight fraction of silt+clay $<2 \%$, we expected changes in habitat quality to provide a causal explanation for the potential effect of the OWF on the sandeel community. A Before-After-Control-Impact (BACI) analysis was applied. A baseline survey from March 2002 (prior to construction) was combined with surveys conducted in March 2004 (short-term effects) and March 2010 (long-term effects) plus an additional survey in September 2009. Sandeels were collected using a modified scallop dredge and sediment samples using a van Veen grab. The results from an analysis on all species combined revealed a positive short-term effect on the densities of both juveniles and adults, which was consistent with a reduction in the fraction of silt+clay. In the long term, a negative effect on juveniles was found; however, this effect was neither consistent with the additional survey in 2009 nor the silt+clay fraction. Subsequent analysis at the species level revealed that the effects detected were driven by Hyperoplus lanceolatus, which dominated the study area in all years. Habitat quality was high in both the affected and control area throughout the study period.
\end{abstract}

KEY WORDS: Offshore construction - Environmental impact assessment - Marine protected area · Marine strategy framework directive $\cdot$ Anthropogenic effect $\cdot$ Ammodytes $\cdot$ Hyperoplus $\cdot$ BACI

\section{INTRODUCTION}

The multitude of human activities in the world's seas has caused global concerns regarding the state of marine ecosystems, resulting in a rapid evolution towards ecosystem-based management of maritime sectors as well as an integrated spatial approach to planning and management of activities at sea. Ambitious targets for development of renewable energy sources have in recent years been one of the main drivers of this evolution. Our study is concerned with offshore wind farms (OWFs), which are increasing rapidly in numbers and size. OWFs differ from many other maritime activities as it has been hypothesized that they could induce positive effects on the marine ecosystem (e.g. Côté et al. 2001, Petersen \& Malm 2006, Reubens et al. 2011). Nevertheless, peerreviewed scientific documentation of the effects of OWF development on the aquatic fauna is rare (Wahlberg \& Westerberg 2005, Wilhelmsson et al. 2006, Wilhelmsson \& Malm 2008, Andersson \& Öhmann 2010, Lindeboom et al. 2011).

OWFs may induce positive ecosystem effects for 2 reasons. (1) Fishing is usually prohibited within the OWF and in the adjacent exclusion zone, i.e. OWFs acting as de facto marine reserves. (2) The founda- 
tions of the turbines are often secured with boulders on the surrounding seabed. These may act as artificial reefs which have been demonstrated to enhance local species diversity and in a few cases also biomass production (Randall 1963, Davis et al. 1982, Ambrose \& Anderson 1990, Coleman \& Connell 2001, Gray 2006, Arena et al. 2007).

However, existing and planned OWFs in the North Sea are located on sandy bottoms that are inhabited by a species community very different from that of boulder reefs. A full understanding of the potential ecological consequences of building OWFs in the North Sea therefore requires knowledge of not only the artificial reef effect, but also of the effects on the sand habitats and their inhabitants (e.g. Davis et al. 1982, Ambrose \& Anderson 1990).

Rather than attempting to analyse the effects on the sand-bottom community as a whole (molluscs, annelids, fish etc.), the focal point of this study will be on the semi-pelagic and sand-dwelling sandeel.

Sandeels comprise of a group of phylogenetically related fish species that, due to their vast numbers and high oil content, play a key role in the North Sea. Sandeels are important prey for a number of predators including fish, seabirds and marine mammals, and constitute the basis for a large-scale fishery producing raw material for the fish meal and oil industry (e.g. Robards 2000, Furness 2002, Frederiksen et al. 2005, Wanless et al. 2005, MacLeod et al. 2007, Dankel et al. 2008, Sharples et al. 2009, Jensen et al. 2011). During the growth season (spring and early summer), sandeels feed in the water column during the day and bury themselves into the sand during the night in habitats consisting of well-oxygenated sand, preferably with a weight fraction of silt+clay $<2 \%$ (Winslade 1974, Jensen 2001, Wright et al. 2000, van Deurs et al. 2011). Outside the growth season, sandeels rarely leave their refuge in the sand (e.g. Winslade 1974, Wright et al. 2000, Høines \& Bergstad 2001, van Deurs et al. 2010). During spawning, eggs adhere to the substrate and hatched larvae are dispersed by currents until metamorphosis (Jensen et al. 2003). The most studied species, the lesser sandeel Ammodytes marinus, is transported over considerable distances from hatch sites by ocean currents during the larval phase. At spawning banks close to the study site, larval transport is estimated to be between 50 and $100 \mathrm{~km}$ (Christensen et al. 2008). After metamorphosis, juveniles settle in suitable habitats, with a low silt+clay weight fraction and of intermediate depth (Wright et al. 2000, Jensen 2001), after which they show high bank fidelity, i.e. possibly with some redistribution but with no indication of migration outside their 'home sand bank' (Jensen et al. 2011). These attributes have contributed to the recent nomination of the sandeel as a candidate indicator species of the health of the North Sea Ecosystem (Rogers et al. 2010).

Sandeel behaviour and its relevance as an ecosystem health indicator, viewed within the context of an increasing number of OWFs in the North Sea, emphasizes the importance of asking: What effects does the construction of OWFs have on sandeel densities? Since large advective and diffusive processes are expected to influence larval drift of all sandeel species, the important processes within the present context are habitat choice in relation to settling after metamorphosis as well as adult redistribution (Holland et al. 2005). Additionally, since sandeels display a distinct preference for sand habitats with a low content of silt+clay, OWF-induced changes in habitat quality may provide the causal explanation for any change in sandeel densities that may occur in the post-construction phase.

Here we approached this question by using a BACI approach (Before-After-Control-Impact) to examine the effect of the OWF, named Horns Rev I, on (1) densities of 3 species of sandeel (Ammodytes marinus, $A$. tobianus and Hyperoplus lanceolatus) and (2) sand habitat quality (weight fraction of silt+clay in the sediment). Horns Rev I is a medium-large OWF constructed in 2002 to 2003 on a sand bank $15 \mathrm{~km}$ off western Denmark in the North Sea. To satisfy the BACI design, data was collected before and after construction of Horns Rev I, both inside the affected area and from a closely situated control area. Since wave action at the shallow water depths and strong tidal currents off the SW Jutland coast (Huess 2001) influence sediment transport and local topography (Andersen 1999, Larsen 2003), no assumptions of fixed station effects were made, and instead, a randomised sampling design within impact and control areas was chosen among years.

\section{MATERIALS AND METHODS}

\section{Surveys, selection of sampling positions, and sampling frequency}

The study area is dominated by sand and relatively shallow depths (10 to $20 \mathrm{~m}$ ) influenced by waves and tidal water movements. The construction of the OWF called Horns Rev I began in March 2002 and was completed in early 2003. The OWF covers $27.5 \mathrm{~km}^{2}$ 
and its 80 turbines stand $560 \mathrm{~m}$ apart in a regular grid formation (Fig. 1). Data for a BACI (Before-AfterControl-Impact) analysis were collected during daytime surveys (08:00 am to 06:00 pm) in the impact area and a control area located $\sim 3 \mathrm{~km}$ northwest of the OWF. Surveys were carried out between 8 and 14 March in 2002 (before construction), 2004 (1 yr after construction: short-term effects) and 2010 (7 yr after construction: long-term effects).

Random selection of sampling position was based on 63 positions defined in a grid in the impact area and 9 positions in the control area (Fig. 1). In 2002, a total of 9 sampling positions from the impact area and 3 from the control area were randomly selected from the respective grids. We revisited 5 out of the 9 positions visited in the impact area in 2002 and all 3 posi-

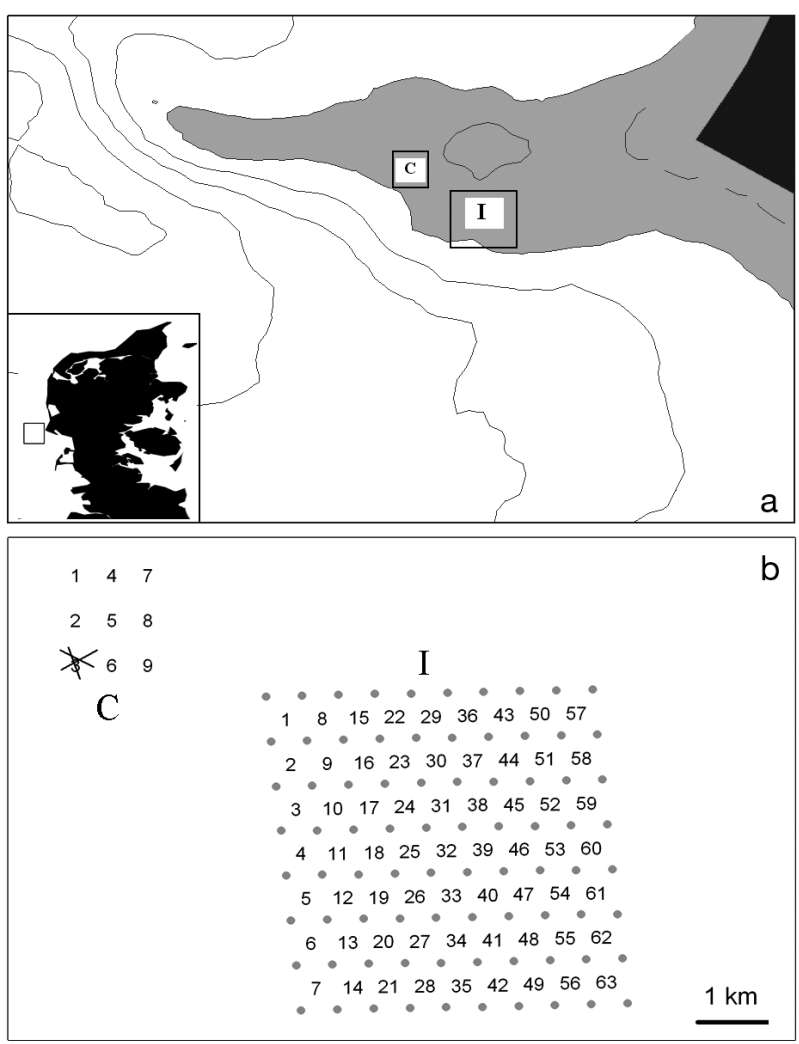

Fig. 1. Horns Rev located 14 to $20 \mathrm{~km}$ off the western coast of Denmark. (a) Inset: location of the study area relative to Denmark. Main panel: location of the study area relative to the topography: Above sealevel = black, depths $<10 \mathrm{~m}=$ grey, and depths $>10 \mathrm{~m}=$ white. (b) Turbine positions $\left({ }^{\circ}\right)$ and the grids from which sampling positions were selected (1 to 9 in the control area (C) and 1 to 63 in the impact area (I)). As illustrated by transect lines across Sample Position 3, 3 to 5 replicate sandeel hauls were carried out at each selected sample position. The center coordinates of the impact and control area are $7.84^{\circ} \mathrm{E}$ to $55.48^{\circ} \mathrm{N}$ and $7.76^{\circ} \mathrm{E}$ to $55.51^{\circ} \mathrm{N}$ respectively tions in the control area in 2004 and 2010 (randomly selected). In addition, 3 new grid positions from the impact area and 2 and 4 new grid positions from the control area were randomly selected. During all surveys, 3 to 5 sandeel samples and 1 to 5 sediment samples were taken at each selected sampling position (Table 1). Details about the sampling technique 'Sandeel sampling method'.

Sandeel catch rates were very low in the original March 2010 survey. A supplementary survey was therefore carried out 10 d later (March 22 to 23). During this additional March survey, 4 positions each from the impact and control area were randomly selected among the positions in the original March 2010 survey (Table 1). No sediment samples were taken during this survey.

In addition to the daytime March surveys, which was intended to collect data for the BACI analysis, an opportunity to conduct a bonus survey arose in September 2009 (Sept 8 to 10). This survey visited the same positions as in the supplementary 2010 survey, but each position was visited twice, once during the day (08:30 to $14: 00 \mathrm{~h}$ ) and once during the night (22:00 to 05:30) (Table 2). Sandeel data and sediment data from this survey were analysed separately and served 2 purposes: (1) validation of the strength of conclusions made regarding the long-term effect of the OWF and (2) validation of the assumption that any observed difference in catch rates between impact and control was not biased by interacting diurnal effects (see section on sandeel sampling).

\section{Sandeel sampling method}

A $1.25 \mathrm{~m}$ wide modified scallop dredge (ICES 2010) towed behind a research vessel was used to sample sandeels hidden in the sand (between 08:00 and 18:00 h). Each replicate dredge sample represented a $10 \mathrm{~min}$ haul covering a mean distance of $800 \mathrm{~m}$ on a straight line (as indicated in Fig. 1b). Sampling alternated between the impact area and the control area to avoid the influence of potential daytime effects on sandeel catchability. Dredging has previously provided precise measurements of relative densities of sandeels in the seabed (Jensen 2001, van der Kooij et al. 2008). As March is outside the main feeding period of sandeels in the North Sea (e.g. Winslade 1974, Wright et al. 2000, Høines \& Bergstad 2001, Greenstreet et al. 2006), we assumed that the bulk of the sandeel population would reside in the seabed during the day. Sampling at night was not an option due to difficulty of maneuvering between the tur- 
Table 1. Samples collected in the impact area (I) and in a control area (C) for the BACI analysis. Identification numbers of positions (Pos ID) correspond to Fig. 1. No. samples: replicates taken during each survey and at each position (see 'Materials and methods'). The number of individuals caught at each position is given for each sandeel species: H.l. = Hyperoplus lanceolatus; A.m. = Ammodytes marinus; A.t. $=$ A. tobianus, separated by length $(<10 \mathrm{~cm}=$ juvenile, $>10 \mathrm{~cm}=$ adult $)$

\begin{tabular}{|c|c|c|c|c|c|c|c|c|c|c|}
\hline Survey & $\begin{array}{l}\text { Pos } \\
\text { ID }\end{array}$ & Area & $\begin{array}{l}\text { No. sandeel } \\
\text { samples }\end{array}$ & H.l. & $\begin{array}{c}>10 \mathrm{~cm} \\
\text { A.m. }\end{array}$ & $\overline{\text { A.t. }}$ & H.l. & $\begin{array}{l}<10 \mathrm{~cm} \\
\text { A.m. }\end{array}$ & $\overline{\text { A.t. }}$ & $\begin{array}{l}\text { No. sediment } \\
\text { samples }\end{array}$ \\
\hline \multirow[t]{12}{*}{ Mar 2002} & 4 & I & 5 & 8 & 1 & 1 & 21 & 7 & 1 & 5 \\
\hline & 14 & I & 5 & 3 & 5 & 6 & 4 & 3 & 0 & 5 \\
\hline & 15 & I & 5 & 3 & 10 & 3 & 53 & 17 & 1 & 5 \\
\hline & 19 & I & 5 & 6 & 3 & 4 & 5 & 2 & 4 & 5 \\
\hline & 29 & I & 5 & 0 & 6 & 1 & 12 & 11 & 1 & 5 \\
\hline & 33 & I & 5 & 4 & 6 & 9 & 31 & 4 & 1 & 5 \\
\hline & 39 & I & 5 & 1 & 6 & 1 & 29 & 8 & 1 & 5 \\
\hline & 55 & I & 5 & 1 & 10 & 8 & 44 & 5 & 0 & 5 \\
\hline & 57 & I & 5 & 0 & 1 & 1 & 7 & 1 & 0 & 5 \\
\hline & 3 & $\mathrm{C}$ & 5 & 1 & 5 & 3 & 12 & 8 & 0 & 5 \\
\hline & 5 & $\mathrm{C}$ & 5 & 4 & 9 & 5 & 22 & 10 & 3 & 5 \\
\hline & 7 & $\mathrm{C}$ & 5 & 10 & 10 & 1 & 21 & 12 & 2 & 5 \\
\hline \multirow[t]{12}{*}{ Mar 2004} & 4 & I & 4 & 58 & 0 & 0 & 38 & 0 & 0 & 4 \\
\hline & 14 & I & 4 & 6 & 1 & 6 & 23 & 2 & 0 & 4 \\
\hline & 19 & I & 4 & 10 & 0 & 2 & 34 & 0 & 0 & 4 \\
\hline & 33 & I & 4 & 13 & 0 & 1 & 22 & 0 & 1 & 4 \\
\hline & 38 & I & 4 & 9 & 0 & 0 & 32 & 0 & 1 & 4 \\
\hline & 45 & I & 4 & 11 & 0 & 3 & 65 & 0 & 3 & 4 \\
\hline & 57 & I & 4 & 21 & 2 & 2 & 63 & 1 & 2 & 4 \\
\hline & 1 & $\mathrm{C}$ & 4 & 12 & 1 & 2 & 19 & 0 & 1 & 4 \\
\hline & 3 & $\mathrm{C}$ & 4 & 18 & 1 & 1 & 14 & 1 & 0 & 4 \\
\hline & 5 & $\mathrm{C}$ & 4 & 6 & 0 & 0 & 21 & 0 & 0 & 4 \\
\hline & 6 & $\mathrm{C}$ & 4 & 1 & 0 & 0 & 6 & 0 & 0 & 4 \\
\hline & 7 & $\mathrm{C}$ & 4 & 3 & 0 & 0 & 8 & 0 & 0 & 4 \\
\hline Mar 2010 & 4 & I & 3 & 0 & 0 & 0 & 6 & 0 & 1 & 1 \\
\hline \multirow{13}{*}{$\begin{array}{l}\text { Original } \\
\text { survey }\end{array}$} & 14 & I & 3 & 0 & 0 & 4 & 1 & 0 & 0 & 2 \\
\hline & 19 & I & 3 & 0 & 0 & 3 & 3 & 0 & 0 & 2 \\
\hline & 33 & I & 3 & 2 & 0 & 0 & 0 & 0 & 0 & 1 \\
\hline & 38 & I & 3 & 0 & 0 & 2 & 0 & 0 & 0 & 2 \\
\hline & 45 & I & 3 & 0 & 0 & 4 & 1 & 0 & 0 & 1 \\
\hline & 57 & I & 3 & 0 & 0 & 1 & 1 & 0 & 1 & 1 \\
\hline & 1 & $\mathrm{C}$ & 3 & 0 & 0 & 0 & 5 & 0 & 0 & 1 \\
\hline & 3 & $\mathrm{C}$ & 3 & 0 & 2 & 2 & 6 & 1 & 0 & 1 \\
\hline & 4 & $\mathrm{C}$ & 3 & 0 & 0 & 2 & 11 & 0 & 0 & 1 \\
\hline & 5 & $\mathrm{C}$ & 3 & 1 & 0 & 2 & 10 & 0 & 0 & 1 \\
\hline & 6 & $\mathrm{C}$ & 3 & 0 & 0 & 0 & 6 & 0 & 0 & 4 \\
\hline & 7 & $\mathrm{C}$ & 3 & 0 & 0 & 1 & 9 & 0 & 0 & 2 \\
\hline & 8 & $\mathrm{C}$ & 3 & 0 & 0 & 1 & 13 & 0 & 1 & 1 \\
\hline \multirow{8}{*}{$\begin{array}{l}\text { Mar } 2010 \\
\text { supple- } \\
\text { mentary } \\
\text { survey }\end{array}$} & 4 & I & 3 & 0 & 0 & 1 & 11 & 0 & 1 & 0 \\
\hline & 14 & I & 3 & 0 & 0 & 1 & 2 & 0 & 0 & 0 \\
\hline & 19 & I & 3 & 2 & 3 & 4 & 3 & 0 & 0 & 0 \\
\hline & 38 & I & 3 & 0 & 0 & 0 & 0 & 1 & 0 & 0 \\
\hline & 3 & $\mathrm{C}$ & 3 & 1 & 0 & 0 & 17 & 1 & 0 & 0 \\
\hline & 5 & $\mathrm{C}$ & 3 & 0 & 0 & 1 & 3 & 0 & 0 & 0 \\
\hline & 6 & $\mathrm{C}$ & 3 & 1 & 2 & 7 & 10 & 3 & 0 & 0 \\
\hline & 7 & $\mathrm{C}$ & 3 & 0 & 0 & 1 & 5 & 1 & 0 & 0 \\
\hline
\end{tabular}

bines in the dark during harsh weather. The September 2009 survey was, however, an exception as calm weather allowed us to carry out planned nighttime sampling.

All dredged sandeels were frozen for the later laboratory analysis, where they were identified to spe- cies, counted, and the weight $(\mathrm{g})$ and length $(\mathrm{mm})$ of the individuals were measured. Sandeel species were identified using the criterion given in Table 3 . Aging, based on otoliths, was considered to be largely uncertain, as this method has only previously been practiced on Ammodytes marinus. Instead we 
Table 2. Samples taken during the September 2009 survey. This survey covered both the impact area (I) and the control area (C). Identification numbers of positions (Pos ID) correspond to Fig. 1

\begin{tabular}{|cccccc|}
\hline Time & $\begin{array}{c}\text { Pos } \\
\text { ID }\end{array}$ & Area & $\begin{array}{c}\text { No. } \\
\text { sandeel } \\
\text { samples }\end{array}$ & $\begin{array}{c}\text { Total } \\
\text { no. } \\
\text { sandeels }\end{array}$ & $\begin{array}{c}\text { No. } \\
\text { sediment } \\
\text { samples }\end{array}$ \\
\hline Day & 4 & I & 3 & 63 & 1 \\
& 14 & I & 3 & 34 & 1 \\
& 19 & I & 3 & 47 & 1 \\
& 38 & I & 3 & 52 & 1 \\
& 3 & C & 3 & 90 & 1 \\
& 5 & C & 3 & 53 & 1 \\
& 6 & C & 3 & 28 & 1 \\
& 7 & C & 3 & 43 & 1 \\
& 4 & I & 3 & 175 & 0 \\
& 14 & I & 3 & 128 & 0 \\
& 19 & I & 3 & 108 & 0 \\
& 38 & I & 3 & 146 & 0 \\
& 3 & C & 3 & 279 & 0 \\
& 5 & C & 3 & 78 & 0 \\
& 6 & C & 3 & 83 & 0 \\
& 7 & C & 3 & 96 & 0 \\
\hline
\end{tabular}

decided on a crude ontogenetic classification, where juvenile sandeels were defined as individuals $<10 \mathrm{~cm}$ and adults as $>10 \mathrm{~cm}$.

The exact haul distance (HD) (m) for each sample was calculated using the following equation:

$$
\begin{gathered}
H D=\arccos \left\{\sin \left(\frac{L A T_{\text {start }}}{180} \times \pi\right) \times \sin \left(\frac{L A T_{\text {end }}}{180} \times \pi\right)\right. \\
+\cos \left(\frac{L A T_{\text {start }}}{180} \times \pi\right) \times \cos \left(\frac{L A T_{\text {end }}}{180} \times \pi\right) \times \cos \left(\frac{L O N G_{\text {start }}}{180} \times \pi\right. \\
\left.\left.-\frac{L O N G_{\text {end }}}{180} \times \pi\right)\right\} \times 6.378 \times 10^{6}
\end{gathered}
$$

$L O N G_{\text {end }}, L O N G_{\text {start }}, L A T_{\text {end, }}$ and $L A T_{\text {start }}$ are the longitude and latitude (as decimal values) for the start and end positions of the haul.

\section{Sediment sampling method}

Sediment samples were taken by means of a $0.2 \mathrm{~m}^{2}$ van Veen grab. Grab samples are point samples, and may therefore not represent the sediment composition along the entire haul track that makes up the sandeel sample. Each sediment samples were emptied into a plastic container and a subsample of $\sim 5 \mathrm{~kg}$ of the total sample was taken. The sediment samples were dried for $24 \mathrm{~h}$ at $100^{\circ} \mathrm{C}$ and homogenized afterwards. A subsample (100 to $140 \mathrm{~g}$ ) was sieved through a standard Wentworth series of sieves ranging from 2000 to $63 \mu \mathrm{m}$ mesh, with the aid of a mechanical shaker. The sieve analyses were carried out by the Geological Survey of Denmark and Greenland (GEUS) following the standard DS 405.9. Finally, the weight fraction (\%) of silt+clay (particles $<0.09 \mathrm{~mm}$ ) in each sediment sample (weight fraction of particles $<0.09$ divided by the weight fraction of particles $>0.09$ multiplied by $100 \%$ ) was calculated.

\section{Statistical model}

The following null hypothesis was tested: the OWF has neither short-term nor long-term effects on sandeel densities and habitat quality within the impact area. Testing of the null hypothesis was carried by testing for significant cross effects between

Table 3. Ammodytes marinus, A. tobianus, Hyperoplus lanceolatus, Gymnammodytes semisquamatus. Meristic and biological characteristics of 4 sandeel species. Based on Reay (1970, 1973, Reay et al. 1986) and Macer (1966), except *, which is a new character discovered by H. Jensen, Danish Institute of Aquatic Reseources. nd: no data

\begin{tabular}{|lcccc|}
\hline Characteristic & A. marinus & A. tobianus & H. lanceolatus & G. semisquamatus \\
\hline Spawning time & Dec-Jan & Feb-Apr/Sep-Nov & Summer & Summer \\
Habitat depth & $30-150 \mathrm{~m}$ & $\sim 0-30 \mathrm{~m}$ & $\sim 0-150 \mathrm{~m}$ & $20-200 \mathrm{~m}$ \\
Premaxillae protrusible & Yes & Yes & No & Yes \\
Dark spot on either side of snout & No & No & Yes & No \\
Lateral line system & Not branched & Not branched & Not branched & Aranched \\
Single bicuspid tooth & Absent & Absent & Present & nd \\
Scales at base of caudal fin & Max. 2 to 3, & Min. 6 & Absent & Absent \\
& (extremely rarely) & & $65-69$ & $65-72$ \\
M-band at the base of the caudal fin* & Absent & Present & $53-60$ & $56-59$ \\
Total vertebral number & $65-75$ & $61-66$ & $27-32$ & $28-32$ \\
Dorsal fin ray number & $56-63$ & $49-58$ & $24-32$ & \\
Anal fin ray number & $29-33$ & & & \\
\end{tabular}


Control-Impact and Before-After (Smith 2002). In other words, we looked for temporal changes that occur asynchronously between impact and control area. Temporal changes occurring synchronously in the impact and control area are assumed to be independent of the OWF. Regarding sandeel densities, the null hypothesis was tested using the following negative binomial model, incorporating random effects of sampling position (Pos) and survey (Surv) and a fixed effect of $H D$ :

Model 1

$$
\begin{aligned}
& \eta=\log (Y)=B A+C I+B A \times C I+\text { Pos }+ \text { Surv }+H D \\
& \text { Position } \sim N\left(0, \sigma_{\text {Pos }}^{2}\right), \\
& \text { Survey } \sim N\left(0, \sigma_{\text {Survey }}^{2}\right), \\
& \log (Y) \sim N B(\eta, \theta)
\end{aligned}
$$

$\eta$ is the number of fish in the sample (or the number of adults or juveniles of a certain species). $B A$ has 2 levels representing 'Before' and 'After' construction of the OWF. Data from 2002 always represented 'Before', whereas 'After' was represented by data from 2004 in the case of short-term effects and 2010 in the case of long-term long-term effects. $C I$ also has 2 levels representing the control area and impact area. $B A \times C I$ represents the cross effect of $B A$ and $C I$, and is the primary target of the test. The random position effect was included to minimize the risk of introducing a bias caused by spatial patterns in sandeel densities. The random survey effect was included solely to allow inclusion of data from the supplementary 2010 survey.

The null hypothesis concerning habitat quality was tested using the following logistic regression:

Model 2

$$
\operatorname{Logit}(P)=B A+C I+B A \times C I+\text { Position }
$$

where $P$ is the probability of finding silt+clay in the sample ( weight fraction of silt+clay). Note that a positive effect of $B A \times C I$ on the weight fraction of silt+clay is expected to have a potential negative effect on sandeel densities, as a higher silt+clay fraction suggests a degradation of the habitat quality (Wright et al. 2000, Jensen 2001).

To maintain a common statistical framework throughout the study, data collected during the September 2009 survey was also analysed using the models described above. Except for sandeel data the Before-After term $(B A)$ was replaced by a Day-Night term, and for sediment data both $B A$ and the cross effect $(B A \times C I)$ was left out.

The threshold for rejection of the null hypothesis was defined as $p=0.05$. We distinguished between significant $\left({ }^{*}: 0.05>\mathrm{p}>0.01\right)$, very significant $\left({ }^{* *}: 0.01>p>0.001\right)$, and highly significant $\left({ }^{* * *}: p<\right.$ 0.001 ). The glmm.admb and glm packages in R software (Anonymous 2007) were used to implement the statistical models. P-values were generated using a maximum likelihood ratio test.

\section{RESULTS}

\section{Effects on sandeel densities}

A significant positive short-term effect of the OWF on both juvenile and adult sandeel densities and a significant negative long-term effect on only juvenile sandeel densities was found. These findings followed from significant cross effects, denoted $B A \times C I$ in the statistical model (Fig. 2) (Table 4, test nos. 1 to 4 ). Subsequent analysis at the species level revealed that the effects found were driven
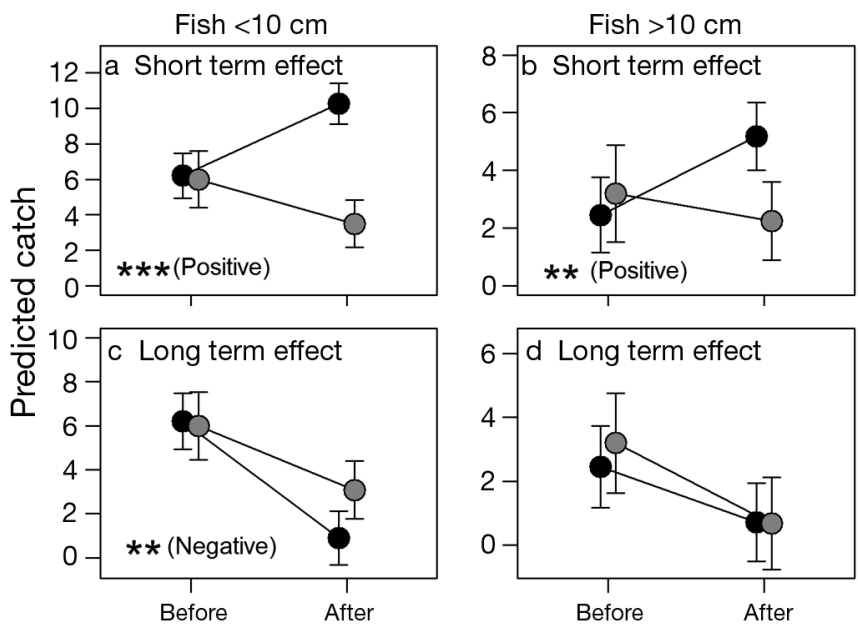

Fig. 2. BACI analysis on all species combined: (a) Short-term effects on juvenile (fish $<10 \mathrm{~cm}$ ) densities. (b) Short-term effects on adult (fish $>10 \mathrm{~cm}$ ) densities. (c) Long-term effects on juvenile densities. (d) Long-term effects on adult densities. Graphs are model estimates of sandeels per sample (1 sample = 10 min dredge haul; means \pm SE) for impact area (O) and control area (O) (the statistical model is described in 'Materials and methods'). The number of asterisks refers to the level of significance in the cross effect of Before-After and Impact-Control $(B A \times C I)\left({ }^{*}: 0.05>p>0.01 i^{* *}: 0.01>p\right.$ $\left.>0.001 ;{ }^{* * *}: \mathrm{p}<0.001\right)$. Whether the effect was negative or positive is shown in parentheses 
Table 4. Cross effects of Before-After Control-Impact ( $B A \times$ $C I$ in model 1 and model 2). Pos or neg indicates whether the effect was positive or negative. Test nos. 1 to 4 were done on all species combined, whereas Test nos. 5 to 10 were done on each species separately, Hyperoplus lanceolatus (H.l.), Ammodytes marinus (A.m.) and A. tobianus (A.t.), but for all sizes combined. $\mathrm{ST}=$ short-term effect on; $\mathrm{LT}=$ long-term effect on. ${ }^{a}$ Negative effect on silt+clay corresponds to a positive effect on habitat quality

\begin{tabular}{|clccc|}
\hline $\begin{array}{l}\text { Test } \\
\text { no. }\end{array}$ & $\begin{array}{l}\text { What was } \\
\text { tested }\end{array}$ & Model & $\mathrm{p}$ & $\begin{array}{c}\text { Pos/ } \\
\text { neg }\end{array}$ \\
\hline 1 & ST juvenile sandeels & 1 & $<0.001$ & Pos \\
2 & ST adult sandeels & 1 & $<0.01$ & Pos \\
3 & LT juvenile sandeels & 1 & $<0.01$ & Neg \\
4 & LT adult sandeels & 1 & 0.59 & \\
5 & ST H.l. & 1 & $<0.01$ & Pos \\
6 & ST A.t. & 1 & 0.06 & \\
7 & ST A.m. & 1 & 0.98 & \\
8 & LT H.l. & 1 & $<0.001$ & Neg \\
9 & LT A.t. & 1 & 0.78 & \\
10 & LT A.m. & 1 & 0.50 & \\
11 & ST silt+clay & 2 & 0.01 & Neg $^{\mathrm{a}}$ \\
12 & LT silt+clay & 2 & 0.19 & \\
\hline
\end{tabular}

solely by Hyperoplus lanceolatus (Table 4, test nos. 5 to 10), which was the most abundant of the 3 species in all years. Densities of $H$. lanceolatus increased in the impact area in 2004 and decreased in 2010 to a level well below that of 2002, whereas $H$. lanceolatus in the control area showed a more stable moderate decline throughout the study period. Ammodytes tobianus and A. marinus fol- lowed a declining pattern throughout the study period that was similar in both the impact area and control area, with $A$. marinus showing the steepest decline (Fig. 3). Altogether 1236 sandeels were caught during the March surveys comprising the BACI analysis (Table 1).

\section{Effects on sediment (habitat quality)}

Only a positive short-term effect of the OWF on habitat quality was found (Fig. 4). This finding followed from a significant negative effect of $B A \times C I$ on the weight fraction of silt+clay (Table 4 , test no. 11), which arose from an increase of silt+clay in the control area rather than a decrease in the impact area. In the long-term (between 2002 and 2010), the weight fraction of silt+clay declined in both the impact area and control area. In general, the silt+clay weight fraction varied little among samples both within and between survey years. The mean silt+clay weight fraction was below $1.2 \%$ in all years in both the impact area and control, and the highest weight fraction observed in a sample was $1.8 \%$ (from the impact area in 2002) (Fig. 5).

\section{September 2009 survey}

Samples taken at night contained highly significantly more sandeels (approx. 3 times as many) than
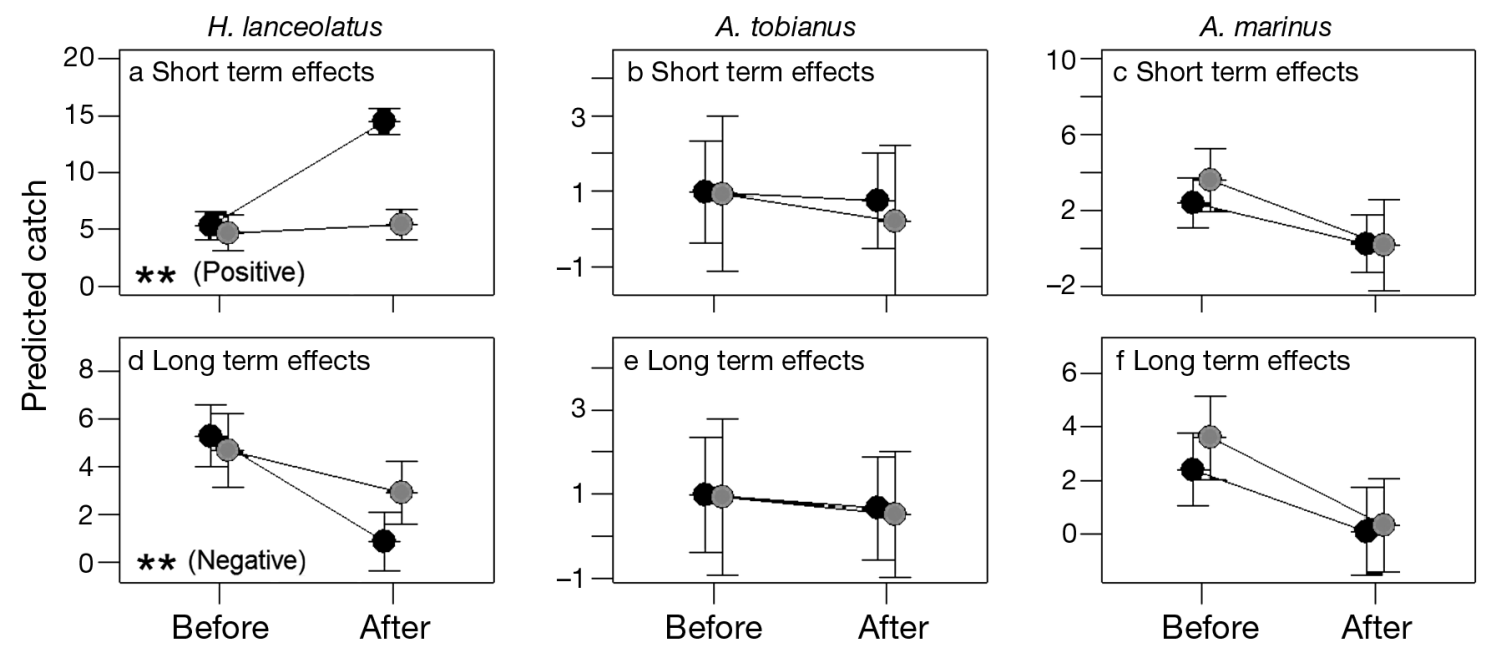

Fig. 3. Hyperoplus lanceolatus, Ammodytes marinus, and A. tobianus. BACI analysis carried out at the species level, adults and juveniles pooled. $(\mathrm{a}-\mathrm{c})$ Short-term effects and $(\mathrm{d}-\mathrm{f})$ long-term effects on sandeel densities. Graphs are model estimates of sandeels per sample (1 sample $=10$ min dredge haul; means \pm SE) for impact area (O) and control area (O) (the statistical model is described in 'Materials and methods'). The number of asterisks refers to the level of significance in the cross effect of Before-After and Impact-Control $(B A \times C I)\left({ }^{*}: 0.05>\mathrm{p}>0.01 ;^{* *}: 0.01>\mathrm{p}>0.001 i^{* * *}: \mathrm{p}<0.001\right)$. Whether the effect was negative or positive is shown in parentheses 

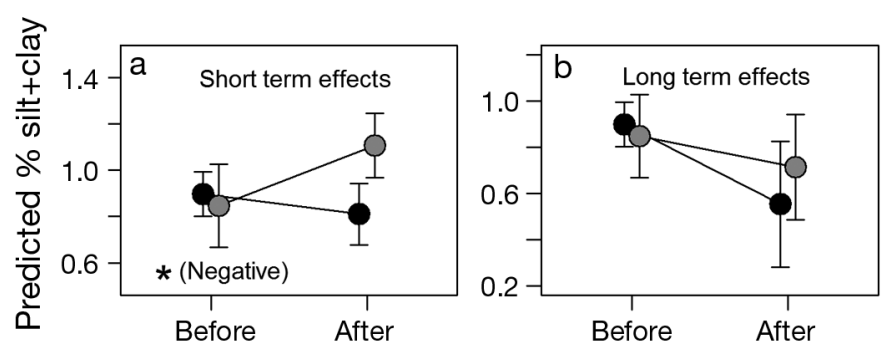

Fig. 4. BACI analysis of habitat quality. (a) Short-term effects and (b) Long-term effects. Graphs are model estimates of the silt+clay weight fraction (means \pm SE) for impact area (-) and control area (O) (the model is described in 'Materials and methods'). The number of asterisks refers to the level of significance in the cross effect of Before-After and Impact-Control $(B A \times C I)\left({ }^{*}: 0.05>p>0.01 ;{ }^{* *}: 0.01>p\right.$ $\left.>0.001 ;{ }^{* * *}: \mathrm{p}<0.001\right)$. Whether the effect was negative or positive is shown in parentheses. A negative effect on the fraction of silt+clay corresponds to a positive effect on habitat quality

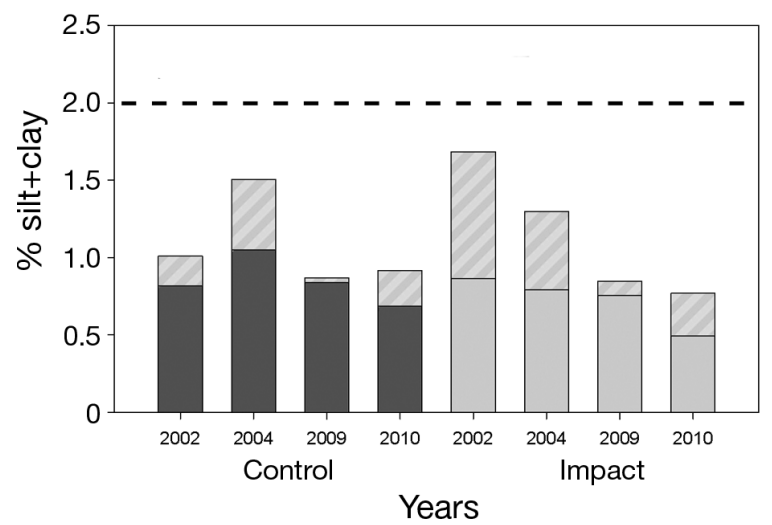

Fig. 5. Silt+clay weight fraction (means) in the control area (dark bars) and impact area (light bars) for all surveyed years. Striped bars: maximum weight fraction observed in a single sample. Dashed horizontal line: $2 \%$ tolerance limit (see 'Introduction')

those taken during the day $(\mathrm{p}<0.001)$. However, overall sandeel densities did not differ significantly between the impact area and the control area $(p=$ 0.87 ) and there was no significant cross effect between Night-Day and Control-Impact $(p=0.24)$ (Fig. 6). Daytime sandeel densities were considerably higher than what was found 6 mo later during the March 2010 surveys but comparable to densities encountered during the earlier March surveys. There was no significant difference in the silt+clay weight fraction between the impact area and control area $(p=0.70)$, and the silt+clay weight fraction was comparable to that of the 3 March surveys (Fig. 5). Altogether, 1503 sandeels were caught during the 2009 survey (Table 2).
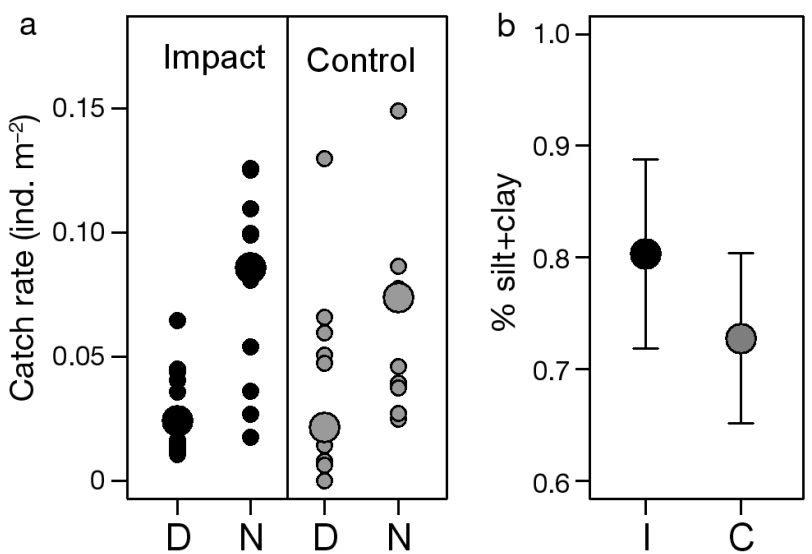

Fig. 6. Results of the September 2009 survey. (a) Effects of Day-Night (D, N) and Control-Impact on sandeel densities (all species combined). $y$-axis: numbers of sandeels per $\mathrm{m}^{2}$ dredged, calculated as total number of sandeels in a given sample divided by the swept area (haul distance $\times$ dredge width). Small dot $=1$ sample $=10$ min dredge haul. Large dot $=$ median value. There were no significant effects. (b) Weight fraction of silt+clay (mean $\pm \mathrm{SE}$ ) for the impact area (I) and control area (C) respectively

\section{DISCUSSION}

The BACI analysis on all species combined revealed a positive short-term effect (1 $\mathrm{yr}$ after construction) on the densities of both juvenile and adult sandeels, which was consistent with a reduction in the silt+clay weight fraction in the sediment (improving habitat quality). In the long-term ( $7 \mathrm{yr}$ afterconstruction), a negative effect on juvenile sandeels was suggested by parts of the data (March 2010) which, however, could not be explained by degradation of habitat quality. The picture was not consistent with what was observed just 6 mo earlier during an additional September 2009 survey, when no difference between impact and control was detected. Analysis at the species level revealed that the effects were reflected only in Hyperoplus lanceolatus, which greatly dominated the study area in all survey years. Ammodytes tobianus and A. marinus were less abundant and there were no differences between impact and control area. A. marinus became exceedingly less common over the course of the study period without any obvious explanation. Hence, we suggest that the presence of A. marinus in the study area depends on an occasional influx of larvae from offshore regions where A. marinus is the dominant sandeel species, and that the study area therefore is a sink rather than a source for $A$. marinus.

Overall, catch rates of sandeels in the present study resembled catch rates experienced during the annual 
sandeel survey (using a identical sandeel dredge) in the shallow coastal parts of the eastern North Sea (ICES 2012). However, dredge catch rates on the main fishing grounds of Dogger Bank are usually in the order of 10 times higher (van der Kooij et al. 2008, ICES 2012).

Lindeboom et al. (2011) studied the short-term effects on sandeels of an OWF located in the Dutch coastal zone $\sim 500 \mathrm{~km}$ southwest of Horns Rev I. Their findings on the effects on sandeel densities are in line with our results, indicating that construction of OWFs may have a positive short-term effect on sandeel densities in the impact area. Lindeboom et al. (2011) found Ammodytes tobianus and A. marinus to be the dominant fish species $1 \mathrm{yr}$ after the construction phase, whereas in the present study Hyperoplus lanceolatus were encountered more frequently. Lindeboom et al. (2011) did not address long-term effects.

Numerous studies have shown that sandeels have a particular preference in regard to grain size composition (Pearson et al. 1984, Pinto et al. 1984, Wright et al. 2000, Jensen 2001, Holland et al. 2005). Holland et al. (2005) concluded that a weight fraction of $6 \%$ silt+clay in the sediment is the upper limit tolerated by sandeels. Wright et al. (2000) found that Ammodytes marinus densities were relatively lower in areas where the silt+clay weight fraction ranged from 2 to $10 \%$ than in areas where the weight fraction was $<2 \%$. Pearson et al. (1984) and Pinto et al. (1984) argued that differences in sediment preference between different species of sandeel were minimal. In summary, the aforementioned studies strongly suggest that the silt+clay weight fraction in the sediment provides a strong indicator of sandeel habitat quality.

In relation to the present study, the silt+clay weight fraction in the sediment was not found to be $>1.8 \%$ in any single sample, suggesting high quality habitat in both the impact area and control area throughout the study period. Hence, we speculate whether the concurrence of a positive short-term effect on sandeel densities and a small increase in silt+clay may merely be coincidental. That the positive effect on sandeel densities was limited to 1 out of the 3 sandeel species, together with the absence of any relationship between the negative long-term effect on juvenile Hyperoplus lanceolatus and habitat quality, adds to this notion.

Alternative explanations for the observed effects on sandeel densities may involve temporary shifts in predator abundance and patchy sandeel distribution.

Previous studies have indicated a period of 3 to $5 \mathrm{yr}$ for stable fish communities to establish after intense disturbance of the existing habitats or introduction of a new habitat (Gray 2006, Petersen \& Malm 2006). If abundance of piscivorous fish, such as larger gadoids, declined temporarily after the construction phase and returned in greater numbers 3 to $5 \mathrm{yr}$ later, this could explain the observed effects of the OWF on sandeel densities. However, results from a study conducted in parallel to the present study contradict this explanation (Stenberg et al. unpubl., National Institute of Aquatic Resources, Denmark).

Sandeels are also an important food source for sea birds (Rindorf et al. 2000) and seals (Furness 2002). A bird survey of the Horns Rev area (Petersen 2005) concluded that of the piscivorous birds present, divers Gavia sp. and razorbill Alca torda showed an increased avoidance of the OWF area. Conversely, herring gull Larus argentatus, little gull Hydrocoloeus minutus and common tern Sterna hirundo exhibited an increased preference for the OWF area. Herring gulls were the most abundant piscivorous bird species present, and may use the turbines as loafing structures. Herring gulls are not capable of plunge diving and feed mainly on fish available directly at the surface. Hence, in order for herring gulls to pose a threat, other predators must drive the sandeels up from below. Such a predator could, for example, be the harbour seal, which is known to frequent the area (Taugaard et al. 2006). The possibility of these kinds of complex interactions between predatory species and the decreased sandeel densities found in March 7 yr after construction, invites further studies.

Lastly, small-scale patchiness of sandeel distribution, attributed to factors other than habitat quality, could have resulted in differences between the impact and control area and thereby created the illusion of an OWF effect. It is possible that the negative long-term effect, which was isolated to juvenile Hyperoplus lanceolatus in March 2010, is caused by small scale patchiness in local recruitment patterns. This would also explain why there was no difference between the impact and control area in September 2009, where recruitment of young-of-the-year H. lanceolatus would still not have taken place (Macer 1966, Reay 1970). In retrospect, this type of uncertainty may have been avoided if a second control area east of the impact area had been included.

Several authors have argued that OWFs have potential positive impacts on the local ecosystem due to artificial reef effects and the closure of commercial fishing as in marine protected areas (MPAs) (e.g. Côté et al. 2001, Petersen \& Malm 2006, Reubens et al. 2011, Fenberg et al. 2012). A poten- 
tial positive MPA-effect seems likely in relation to the sand-dwelling sandeel, and the establishment of MPAs has previously been suggested as a management tool in relation to sandeels in the North Sea (Christensen et al. 2009). According to Vessel Monitoring System (VMS) data generated from the area, commercial fishing for sandeels in 2009 and 2003 occurred in close proximity to the boundaries of Horns Rev I (see Fig. 7). However, fishing activity in the control area was low, which may have prevented us from detecting a potential MPA-effect (see Bastardie et al. 2010 for details on the use of VMS data). Another explanation for this may be that the home range of sandeels in the present
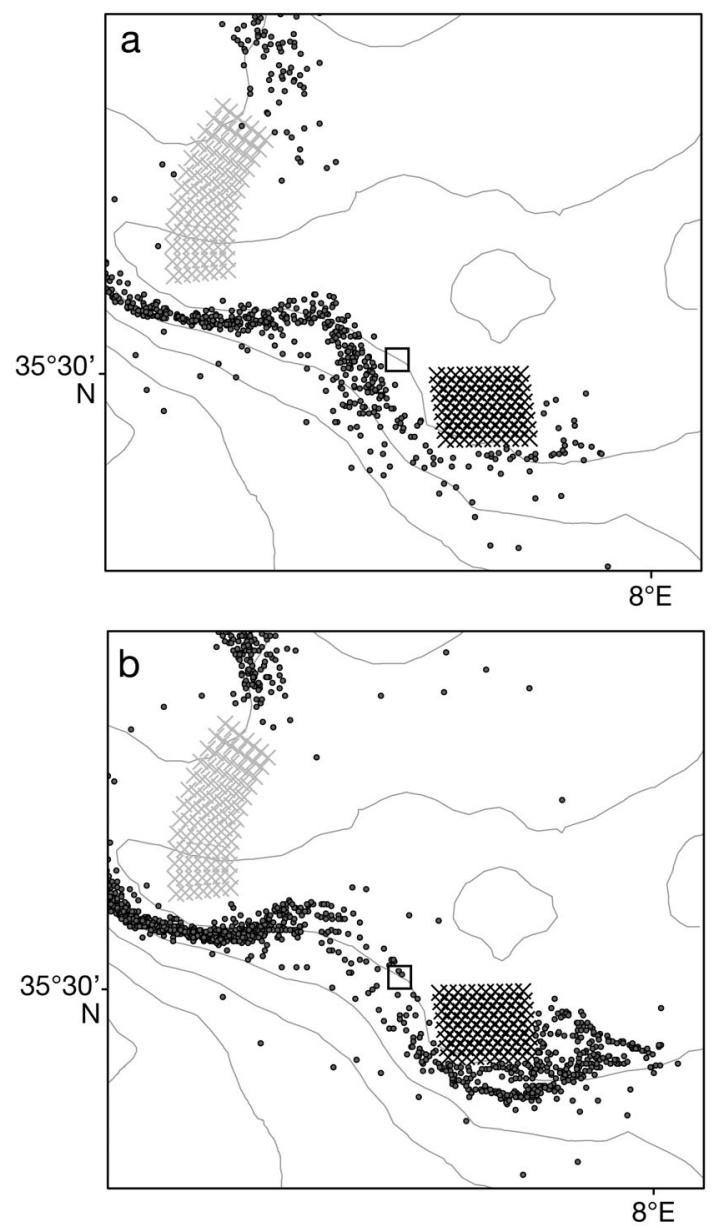

Fig. 7. Sandeel fishing activity in (a) 2003 and (b) 2009. Hourly satellite recordings $(\bullet)$ of sandeel fishing vessels traveling 2 to 4 knots. In 2003, only vessels > 24 m were equipped with vessel monitoring systems (VMS), whereas in 2009, all vessels $>15 \mathrm{~m}$ were equipped with VMS (see Bastardie et al. 2010 for details on the use of VMS data). (x): Horns Rev I finished in 2003 (lower right corner) and $(x)$ Horns Rev II finished in 2009 (upper left corner). The center coordinates of the impact and control area are $7.84^{\circ} \mathrm{E}$ to $55.48^{\circ} \mathrm{N}$ and $7.76^{\circ} \mathrm{E}$ to $55.51^{\circ} \mathrm{N}$ respectively study area is considerably larger than the size of Horns Rev I plus control area, and sandeels therefore freely move between the impact area and the control area (Kramer \& Chapman 1999, Engelhard et al. 2008). The home range of Ammodytes marinus on some of the more isolated banks in deeper water further offshore is likely to be considerably smaller than in shallow coastal areas with high habitat connectivity (Jensen et al. 2011). We therefore cannot exclude the possibility that, given the OWF is large enough and built in a suitable location, it may serve as a MPA. Furthermore, it cannot be ruled out that closures of areas that would otherwise have been fished might provide sites for undisturbed spawning, which in turn may provide benefits (i.e. reserve effects) for sandeel populations beyond the local scale through long distance drifting of the larvae (especially for Hyperoplus lanceolatus, which spawns during summer when fishing takes place).

EU's Marine Strategy Framework Directive (MSFD) aims to achieve 'good environmental status' (GES) for European seas by 2020 (Rogers et al. 2010). The MSFD focuses on 11 qualitative descriptors, of which at least 4 have direct or indirect relevance to sandeels and their habitats and which may be sensitive to inappropriate siting of offshore installations such as OWFs. Furthermore, the EU's Maritime Policy calls for an ecosystem approach to integrated planning of maritime activities, which aims for sustainable growth of maritime activities while ensuring that these activities develop in a way that does not threaten marine ecosystem health. Given the increasing rate and scale of OWF development in the North Sea, the methods and results of our study may serve as a contribution to informed decision-making regarding the short-term and long-term impacts related to OWF development in the North Sea.

In conclusion, the present study shows that, within a time window of $7 \mathrm{yr}$ after construction, the OWF represents neither a direct benefit nor a definite threat to sandeels and their sand habitat. However, (1) we failed to explain why reduced sandeel densities was observed in the impact area in March 2010, but not in September 2009; (2) the conclusions were mainly driven by Hyperoplus lanceolatus, which dominated the near-shore study area. Sand banks further offshore (i.e. Dogger Bank) possess higher densities of sandeels, and mainly of the species Ammodytes marinus (ICES 2012), which differ from H. lanceolatus on several aspects (Macer 1966, Reay 1970). Consequently, the conclusion drawn from the present study may not be directly applicable to OWFs built in densely populated offshore areas such 
as Dogger Bank. Lastly, we do not know what will happen 10, 20 or $50 \mathrm{yr}$ into the future.

Having said that, we still suggest that these results, combined with the results from other recent studies (e.g. Lindeboom et al. 2011), represent the beginning of a much needed knowledge base required for informed decision-making regarding placement of OWFs and their effects on the marine environment. At the moment this knowledge base is in particular need of studies addressing effects that take place over periods of 10 to 20 yr from the time of construction.

Acknowledgements. The study is part of The Environmental Monitoring Programme for the Danish offshore demonstration wind farms Horns Rev 1 and Nysted, administered by The Environmental Group consisting of the Danish Energy Agency, the Danish Nature Agency, Vattenfall and DONG Energy. The work was conducted under contract with Vattenfall Vindkraft A/S, and sponsored by the Danish energy consumers through a public service obligation. We acknowledge J. Egekvist for providing the VMS data, C. Berg for guidance on choice of statistical models, and 4 anonymous referees for providing useful comments that helped improve the manuscript.

\section{LITERATURE CITED}

Ambrose RF, Anderson TW (1990) Influence of an artificial reef on the surrounding infaunal community. Mar Biol 107:41-52

Andersen OB (1999) Shallow water tides in the northwest European shelf region from TOPEX/POSEIDON. J Geophys Res 104(C4):7729-7742

> Andersson MH, Öhmann MC (2010) Fish and sessile assemblages associated with wind turbine constructions in the Baltic sea. Mar Freshw Res 61:642-650

Anonymous (2007) The R project for statistical computing. Accessed: March. www.r-project.org.

> Arena PT, Jordan LKB, Spieler RE (2007) Fish assemblages on sunken vessels and natural reefs in southeast Florida, USA. Hydrobiologia 580:157-171

> Bastardie F, Nielsen JR, Ulrich C, Egekvist J, Degel H (2010) Detailed mapping of fishing effort and landings by coupling fishing logbooks with satellite-recorded vessel geo-location. Fish Res 106:41-53

Christensen A, Jensen H, Mosegaard M, St John M, Schrum C (2008) Sandeel (Ammodytes marinus) larval transport patterns in North Sea from an individual-based hydrodynamic egg and larval model. Can J Fish Aquat Sci 65: 1498-1511

> Christensen A, Mosegaard H, Jensen H (2009) Spatially resolved fish population analysis for designing MPAs: influence on inside and neighbouring habitats. ICES J Mar Sci 66:56-63

Coleman MA, Connell SD (2001) Weak effects of epibiota on the abundances of fishes associated with pier pilings in Sydney Harbour. Environ Biol Fishes 61:231-239

Côté IM, Mosqueira I, Reynolds JD (2001) Effects of marine reserve characteristics on the protection of fish populations: a meta-analysis. J Fish Biol 59:178-189

> Dankel DJ, Skagen DW, Ulltang O (2008) Fisheries manage- ment in practice: review of 13 commercially important fish stocks. Rev Fish Biol Fish 18:201-233

> Davis N, Vanblaricom GR, Dayton PK (1982) Man-made structures on marine sediments: effects on adjacent benthic communities. Mar Biol 70:295-303

Engelhard GH, van der Kooij J, Bell ED, Pinnegar JK, Blanchard JL, Mackinson S, Righton DA (2008) Fishing mortality versus natural predation on diurnally migrating sandeels Ammodytes marinus. Mar Ecol Prog Ser 369: 213-227

Fenberg PB, Caselle JE, Claudet J, Clemence M and others (2012) The science of European marine reserves: status, efficacy, and future needs. Mar Policy 36:1012-1021

Frederiksen M, Wright PJ, Harris MP, Mavor RA, Heubeck M, Wanless S (2005) Regional patterns of kittiwake Rissa tridactyla breeding success are related to variability in sandeel recruitment. Mar Ecol Prog Ser 300:201-211

> Furness RW (2002) Management implications of interactions between fisheries and sandeel-dependent seabirds and seals in the North Sea. ICES J Mar Sci 59:261-269

Gray JS (2006) Minimizing environmental impacts of a major construction: the Øresund link. Integr Environ Assess Manag 2:196-199

Greenstreet SPR, Armstrong E, Mosegaard H, Jensen H and others (2006) Variation in the abundance of sandeels Ammodytes marinus off southeast Scotland: an evaluation of area-closure fisheries management and stock abundance assessment methods. ICES J Mar Sci 63: $1530-1550$

> Høines AS, Bergstad OA (2001) Density of wintering sand eel in the sand recorded by grab catches. Fish Res 49: 295-301

> Holland GJ, Greenstreet SPR, Gibb IM, Fraser HM, Robertson MR (2005) Identifying sandeel Ammodytes marinus sediment habitat preferences in the marine environment. Mar Ecol Prog Ser 303:269-282

Huess V (2001) Sea level variations in the North Sea from tide gauges, altimetry and modelling. PhD thesis. Danish Meteorological Institute, Copenhagen

ICES (2010) Report of the benchmark workshop on sandeel. ICES CM 2010/ACOM:57. International Council for the Exploration of the Sea, Copenhagen

ICES (2012) Working group on the assessment of demersal stocks in the North Sea and Skagerrak. ICES CM 2012/ACOM:13. International Council for the Exploration of the Sea, Copenhagen

Jensen H (2001) Settlement dynamics in the lesser sandeel Ammodytes marinus in the North Sea. PhD thesis, University of Aberdeen

Jensen H, Wright P, Munk P (2003) Vertical distribution of pre-settled sandeel (Ammodytes marinus) in the North Sea in relation to size and environmental variables. ICES J Mar Sci 60:1342-1351

Jensen H, Rindorf A, Wright PJ, Mosegaard H (2011) Inferring the location and scale of mixing between habitat areas of lesser sandeel through information from the fishery. ICES J Mar Sci 68:43-51

> Kramer DL, Chapman MR (1999) Implications of fish home range size and relocation for marine reserve function. Environ Biol Fishes 55:65-79

Larsen B (2003) Blåvands Huk - Horns Rev området-et nyt Skagen? Geologi Nyt fra GEUS nr 4 december 2003. www.geus.dk/publications/geo-nyt-geus/gi034.htm

> Lindeboom HJ, Kouwenhoven HJ, Bergman MJN, Bouma S and others (2011) Short-term ecological effects of an off- 
shore wind farm in the Dutch coastal zone; a compilation. Environ Res Lett 6:035101

Macer CT (1966) Sandeels (Ammodytidae) in the southwestern North Sea: Their biology and fishery. MAFF Fishery Invest.London ser.II 24:1-55

MacLeod CD, Santos MBA, Reid RJ, Scott BE, Pierce GJ (2007) Linking sandeel consumption and the likelihood of starvation in harbour porpoises in the Scottish North Sea: could climate change mean more starving porpoises? Biol Lett 3:185-188

Pearson WH, Woodruff DL, Sugarman PC (1984) The burrowing behavior of sand lance, Ammodytes hexapterus: effects of oil-contaminated sediment. Mar Environ Res 11:17-32

Petersen IB 2005. Bird numbers and distributions in the Horns Rev offshore wind farm area. NERI Report Commisioned by Elsam Engineering A/S. Available at: www. hornsrev.dk/Miljoeforhold/miljoerapporter/horns \%20rev \%20bird\%20numbers.pdf

Petersen JK, Malm T. 2006. Offshore windmill farms: threats to or possibilities for the marine environment. Ambio 35: 75-80

Pinto JM, Pearson WH, Anderson JW (1984) Sediment preferences and oil contamination in the Pacific sand lance Ammodytes hexapterus. Mar Biol 83:193-204

Randall JE (1963) An analysis of fish populations at artificial and natural reefs in the Virgin Islands. Caribb J Sci 3: 31-47

Reay PJ (1970) Synopsis of the biological data on North Atlantic sand eels of the genus Ammodytes. Fisheries Synopsis No. 82. Food and Agriculture Organization of United Nations, Rome

Reay PJ (1973) Some aspects of the biology of the sandeel, Ammodytes tobianus L., in Langstone Harbour, Hampshire. J Mar Biol 53:325-346

Reay PJ, Whitehead PJP, Bauchot ML, Hureau JC (1986) Fishes of the north-eastern Atlantic and the Mediterranean, Vol 2. UNESCO, Paris, p 517-1007

Reubens JT, Degraer S, Vincx M (2011) Aggregation and feeding behaviour of pouting (Trisopterus luscus) at wind turbines in the Belgian part of the North Sea. Fish Res 108:223-227

Rindorf A, Wanless S, Harris MP (2000) Effects of changes in sandeel availability on the reproductive output of seabirds. Mar Ecol Prog Ser 202:241-252

Robards MD, Willson MF, Armstrong RH (2000) Sand lance: a review of biology and predator relations and annotated bibliography. In: Piatt JF (eds) Res. Pap. PNW-RP-521. US Department of Agriculture, Forest Service, Pacific

Editorial responsibility: Jake Rice,

Ottawa, Ontario, Canada
Northwest Research Station, Portland, OR

Rogers S, Casini M, Cury P, Heath M and others (2010) Marine strategy framework directive Task group 4 report, Food Webs. In: Piha H (eds) http://publications. jrc.ec.europa.eu/repository/bitstream/111111111/13627/ $1 / \operatorname{tg} 4 \% 20$ report_final_vii.pdf

Sharples RJ, Arrizabalaga B, Hammond PS (2009) Seals, sandeels and salmon: diet of harbour seals in St. Andrews Bay and the Tay Estuary, southeast Scotland. Mar Ecol Prog Ser 390:265-276

Smith EP (2002) BACI design. In: El-Shaarawi AH, Piegorsch WW (eds) Encyclopedia of Environmetrics, Vol 1. John Wiley, Chichester, p 141-148

Taugaard J, Taugaard S, Jensen RC, Jensen $\mathrm{T}$ and others (2006) Harbour seals at Horns Reef before, during and after construction of Horns Rev offshore wind farm. Available at: www.vattenfall.dk/da/file/Harbour-sealsat-Horns-Reef-b_7843262.pdf

van der Kooij J, Scott BE, Mackinson S (2008) The effects of environmental factors on daytime sandeel distribution and abundance on the Dogger Bank. J Sea Res 60: 201-209

> van Deurs M, Christensen A, Frisk C, Mosegaard H (2010) Overwintering strategy of sandeel ecotypes from an energy/predation trade-off perspective. Mar Ecol Prog Ser 416:201-215

van Deurs M, Behrens JW, Warnar T (2011) Primary versus secondary drivers of foraging activity in sandeel schools (Ammodytes tobianus). Mar Biol 158:1781-1789

> Wahlberg M, Westerberg H (2005) Hearing in fish and their reaction to sounds from offshore wind farms. Mar Ecol Prog Ser 288:295-309

> Wanless S, Harris MP, Redman P, Speakman JR (2005) Low energy values of fish as a probable cause of a major seabird breeding failure in the North Sea. Mar Ecol Prog Ser 294:1-8

Wilhelmsson D, Malm T (2008) Fouling assemblages on offshore wind power plants and adjacent substrata. Estuar Coast Shelf Sci 79:459-466

Wilhelmsson D, Malm T, Ohman MC (2006) The influence of offshore windpower on demersal fish. ICES J Mar Sci 63: 775-784

- Winslade P (1974) Behavioral-studies on lesser sandeel Ammodytes-Marinus (Raitt). 3. Effect of temperature on activity and environmental-control of annual cycle of activity. J Fish Biol 6:587-599

Wright PJ, Jensen H, Tuck I (2000) The influence of sediment type on the distribution of the lesser sandeel, Ammodytes marinus. J Sea Res 44:243-256

Submitted: September 27, 2011; Accepted: March 24, 2012 Proofs received from author(s): June 19, 2012 